\title{
EFEKTIVITAS INOVASI KLINIK GAMPONG DALAM PENGELOLAAN DANA DESA DI KABUPATEN ACEH BARAT
}

\author{
EFFECTIVENESS OF GAMPONG CLINIC INNOVATION IN \\ MANAGEMENT OF VILLAGE FUND AT WEST ACEH DISTRICT
}

\author{
Vellayati Hajad ${ }^{1}$, Kemal Pasya ${ }^{2}$, Ikhsan ${ }^{3}$ \\ Fakultas Ilmu Sosial dan Ilmu Politik, Universitas Teuku Umar ${ }^{1,3}$, Kasi Pemerintahan di Kantor Camat Johan \\ Pahlawan Aceh Barat ${ }^{2}$ \\ email: vellayati.hajad@utu.ac.id, kemalpasya95@yahoo.com, ikhsan.baharudin@utu.ac.id
}

\begin{abstract}
Abstrak
Dana desa yang dianggarkan oleh Pemerintah Pusat untuk Pemerintah Aceh meningkat setiap tahunnya, sebesar 84,3 miliar (2015) dan 249 miliar (2019). Namun, dalam implementasinya belum dapat digunakan secara optimal. tulisan ini membahas tentang keberadaan klinik desa sebagai solusi atas banyaknya keterlambatan dan kesalahan pengelolaan dana desa di Aceh. Klinik gampong adalah program pengembangan kapasitas pemerintah desa melalui pelatihan dan bimbingan, koordinasi, konsultasi, dan berbagi informasi, terutama dalam hal perencanaan dan penganggaran untuk dana desa. Metode penelitian ini menggunakan metode kualitatif dengan pendekatan deskriptif. Informan penelitian ini adalah pemerintah kecamatan, pemerintah desa dan masyarakat. Hasil penelitian menunjukkan bahwa program klinik gampong efektif dalam membantu pengelolaan dana desa di Aceh dengan cara meningkatkan kemampuan pemerintah desa, membantu dalam menyusun rencana pembangunan, membuat laporan pertanggungjawaban keuangan, dan mendampingi proses pemberdayaan masyarakat dengan menerjunkan pendamping desa yang siaga membantu menyelesaikan masalah desa seperti kemiskinan dan pengangguran.
\end{abstract}

Kata Kunci: Dana desa; Efektivitas; Inovasi; Pemerintah Desa

\begin{abstract}
Village funds budgeted by the Central Government for West Aceh District increase every year by 84.3 billion (2015) and 249 billion (2019). However, the implementation cannot be used optimally. This paper discusses the existence of village clinics as a solution to the many delays and mistakes in managing village funds in Aceh. The gampong clinic is a village government capacity building program through training and guidance, coordination, consultation and information sharing, especially in terms of planning and budgeting for village funds. This research method uses qualitative methods with a descriptive approach. The informants of this study were the sub-district government, village government and the community. The results showed that the village gampong program was effective in assisting the management of village funds in Aceh by increasing the capacity of the village government, assisting in developing development plans, making financial accountability reports, and assisting the community empowerment process by fielding village assistants who were prepared to help solve village problems such as poverty and unemployment.
\end{abstract}

Keywords: effectiveness; innovation; village funds; village government 


\section{Pendahuluan}

Desa adalah kesatuan masyarakat hukum yang memiliki wilayah dan menurut UndangUndang No. 6 Tahun 2014 (2014) sebuah desa berwenang untuk mengatur dan mengurus urusan pemerintahan demi kepentingan masyarakat setempat sesuai dengan potensi yang dimiliki desa (Maulana, 2016) dan sebagai implikasi selanjutnya, pemerintah memberikan dana penyelenggaraan pemerintahan di desa yang bernama dana desa dan bersumber dari APBN (Anggaran Pendapatan dan Belanja Negara).

Dana desa pada dasarnya bertujuan untuk meningkatkan pelayanan publik di desa dan berupaya (1) untuk mengurangi angka kemiskinan; (2) memajukan perekonomian desa; (3) mengatasi kesenjangan pembangunan antardesa, dan (4) memperkuat masyarakat desa sebagai subjek pembangunan melalui pemberdayaan masyarakat. Dengan kata lain, tujuan pemberian dana desa adalah untuk dapat lebih mensejahterakan kehidupan masyarakat di desa (Dewanta, 2016).

Namun demikian, penyalahgunaan wewenang dalam pengelolaan dana desa masih sering terjadi terutama dalam hal pertanggungjawaban penggunaan dana desa tersebut (Habibi \& Nugroho, 2018). Sebabnya adalah (1) masih adanya petunjuk peraturan untuk mengelola keuangan tersebut yang belum dapat dipahami oleh aparat pengelola keuangan; (2) mekanisme penggunaan alokasi dana desa yang belum dilakukan sesuai petunjuk teknis yang diatur dalam pengelolaan keuangan desa sehingga kadang terjadi penyimpangan yang dilakukan oleh pejabat pengambil keputusan yang berdampak pada banyaknya kasus korupsi dana desa pasca penerapannya sejak tahun 2015 hingga 2019. Setidaknya menurut ICW (Indonesian Corruption Watch) (2018) korupsi dana desa menempati urutan ketiga sektor yang paling banyak ditangani penegak hukum karena menyumbang kasus korupsi terbesar ketimbang sektor lainnya pada tahun 2018. Sejak 2006 hingga 2017 terdapat 122 terdakwa kasus korupsi dana desa yang menyebabkan kerugian Negara hingga 20,16 miliar. Sebabnya adalah akibat dugaan korupsi seperti pengadaan barang dan jasa fiktif, mark up anggaran, tidak melibatkan masyarakat dalam musyawarah desa, hingga penyelewengan dana desa untuk kepentingan pribadi.

Selain itu, FITRA (Forum Indonesia untuk Transparansi Anggaran) (2018) telah terjadi penyimpangan dalam pengelolaan dana desa, data akhir 2018 di mana Satuan Tugas Dana Desa atau sering disebut Satgas DD setidaknya menerima 14.291 laporan pengaduan masyarakat dan baru 5.067 aduan yang telah diproses. Khususnya aduan terkait korupsi dana desa sebanyak yang dilakukan oleh petugas desa seperti kepala desa, sekretaris desa, dan bendahara desa sejumlah 1.371 aduan. Hal tersebut dapat terjadi karena meskipun bendahara bertanggung jawab sebagai pemegang dan penjaga arus keluar dan masuk dana desa, namun apabila tanpa persetujuan kepala desa maka penyelewengan dana desa tidak dapat terjadi. 
Berbagai laporan tentang tindak pidana korupsi dana desa tersebut terjadi karena laporan dari masyarakat tentang pelayanan publik yang diberikan pemerintah, dugaan penyalahgunaan wewenang, hingga perilaku korupsi aparat desa dalam mengelola dan membelanjakan dana desa. Sebabnya adalah tidak adanya prinsip transparansi, partisipasi, dan akuntabilitas yang seharusnya ada dalam proses pengelolaan dana desa. Hal tersebut tidak mengherankan, mengingat situasi dan kondisi pelayanan yang semakin kompleks di sebuah desa mengharuskan aparat desa harus profesional, transparan, efektif, efisien, akuntabel, dan inovatif dalam melaksanakan pemerintahannya sesuai tuntutan kebutuhan masyarakat, namun seringkali belum dipenuhi oleh perangkat desa (Tjandra, 2003; Widjaja, 2008).

Tabel 1.

Dana Desa Kabupaten/Kota Provinsi Aceh (2019)

\begin{tabular}{|c|c|c|}
\hline No. & Regency & $\mathrm{Rp}$ \\
\hline 1. & West Aceh & 249.48Milyar \\
\hline 2. & Nagan Raya & 174.63Milyar \\
\hline 3. & Sabang & 23.64 Milyar \\
\hline 4. & Aceh Besar & 438 Milyar \\
\hline 5. & Banda Aceh & 74.19 Milyar \\
\hline 6. & Aceh Jaya & 134.07Milyar \\
\hline 7. & Pidie & 525.85Milyar \\
\hline 8. & Aceh Timur & 387.12Milyar \\
\hline 9. & Aceh Utara & 627.98Milyar \\
\hline 10. & Lhokseumawe & 58.77 Milyar \\
\hline 11. & Aceh Barat Daya & 117.95Milyar \\
\hline 12 . & Aceh Tengah & 221.44Milyar \\
\hline 13. & Aceh Selata & 203.65Milyar \\
\hline 14. & Aceh Singkil & 106.90Milyar \\
\hline 15. & Subussalam & 69.33 Milyar \\
\hline 16. & Aceh Tenggara & 283.80Milyar \\
\hline 17. & Gayo Lues & 283.80Milyar \\
\hline 18. & Aceh Tamiang & 170.29Milyar \\
\hline 19. & Langsa & 57.77 Milyar \\
\hline 20. & Bener Meriah & 180.97Milyar \\
\hline 21. & Bireuen & 454.00Milyar \\
\hline 22. & Pidie Jaya & 165.95Milyar \\
\hline 23. & Simeulue & 117.222 .029 \\
\hline
\end{tabular}

Sumber: (Kementerian Keuangan RI, 2019) 
Besarnya dana desa setiap kabupaten/kota di Provinsi Aceh tersebut ternyata juga menyeret banyak aparatur desa ke dalam kasus hukum. Seperti yang terjadi pada Bendahara Desa Lueng Bata Aceh, Hannan Syukri yang didakwa melakukan korupsi penyalahgunaan dana pembangunan tempat ibadah sebesar 150 juta pada tahun 2016 dan akhirnya mendapatkan putusan bersalah dan dihukum 2,5 tahun penjara. Data terbaru pada tahun 2019 dari Kepala Badan pemberdayaan Masyarakat Gampong (DPMG) Provinsi Aceh, Drs. Bukhari, MM menyatakan bahwa data terkini yang mereka miliki di tahun 2018 ada empat kasus korupsi dana desa yang dilakukan kepala desa yaitu, di Kabupaten Pidie, Aceh Jaya, Aceh Timur dan Lhokseumawe dan saat ini sedang di tangani pihak berwajib.

Ada beberapa sebab mengapa hal tersebut terjadi, pertama, kurangnya pengawasan dari proses perencanaan, pengadaan, pelaksanaan, dan laporan pertanggungjawaban. Salah satu penghambat pengawasan anggaran dana desa adalah akuntabilitas penggunaan anggaran yang masih belum dilakukan padahal sesuai undang-undang yang ada penggunaan dana desa harus dipublikasikan kepada masyarakat karena dengan ada keterbukaan maka partisipasi masyaakat juga akan meningkat (Dura, 2016; Makalalag, Nangoi, \& Karamoy, 2017; Riyanto, 2015). Kedua, rendahnya kemampuan aparatur desa dalam membuat perencanaan hingga pelaporan penggunaan dana desa juga sangat penting sebagai upaya membangun integritas aparatur desa di hadapan masyarakat desa (Sulumin, 2015).

Kemampuan aparatur desa yang masih lemah dalam mengelola dana desa menuntut pemerintah untuk memberikan pendampingan dari para pakar, karena jika tidak maka dapat menjerumuskan aparat desa dalam kasus korupsi karena beberapa kasus menunjukkan bahwa kasus hukum juga dapat disebabkan oleh ketidaktahuan dan ketidakmampuan kepala desa dan bendahara dalam membuat dan menyusun perencanaan dan pelaporan penggunaan anggaran dana desa (Moonti \& Kadir, 2018). Tulisan ini ingin menjawab pertanyaan bagaimana efektivitas inovasi klinik gampong dalam pengelolaan dana desa di Kabupaten Aceh Barat?

\section{Metode Penelitian}

Penelitian ini melihat inovasi adalah hal yang penting dilakukan oleh pemerintah daerah khususnya dalam pengelolaan dana desa dan untuk menelusuri hal tersebut maka penelitian ini menggunakan metode penelitian deskriptif kualitatif yang bermaksud untuk memahami fenomena tentang apa yang dialami oleh subjek peneliti secara holistik, dan dengan cara deskripsi dalam bentuk kata-kata dan bahasa dengan mempertimbangkan konteks khusus lokasi penelitian. Pendekatan kualitatif deskriptif dalam penelitian ini tidak semata-mata bertujuan untuk mengungkapkan kebenaran saja, tetapi juga memahami kebenaran tersebut (Craswell, 2014).

Penelitian ini berlangsung dalam bulan Maret hingga bulan Mei 2019 di Kabupaten Aceh Barat, tepatnya di Kecamatan Arongan Lambalek. Alasan dari pemilihan lokasi ini adalah Kecamatan Arongan Lambalek sebagai salah satu kecamatan binaan karena termasuk kecamatan 
termiskin di Aceh Barat dan terdiri dari 27 desa, seperti Ujong Simpang, Rimba Langgeh, Alue Bagok, Panton Makmue, Pribu, Teupin Peraho, Cot Kumbang, Keub, Gunong Pulo, Peulate, Karang Hampa, Kubu, Suak Keumude, Arongan, Seunebok Lhong, Drien Rampak, Ujong Beusa, Simpang Peut, Cot Buloh, Alue Batee, Alue Sundak, Panton Bahagia, Cot Jurumudi, Suak Ie Buso, Suak Bidok, Panton Mutia, Seunebok.

Narasumber penelitian ini berjumlah 23 orang dengan rincian kepala desa (keuchik gampong) berjumlah 5 orang, bendahara desa 5 orang, petugas klinik gampong yang terdiri dari pendamping desa dan pendamping lokal desa 5 orang, Camat Arongan Lambalek 1 orang, staf kecamatan 2 orang dan masyarakat desa 5 orang. Data penelitian ini didapat dari observasi dan wawancara mendalam bersama dengan narasumber penelitian sebagai data primer. Sedangkan data sekunder diperoleh melalui pembacaan terhadap buku, jurnal, media massa dan dokumen tertulis lainnya. Data yang diperoleh kemudian dianalisis dengan cara reduksi data, display data, dan penarikan kesimpulan dari data yang ada agar diperoleh informasi dan data yang cukup bagi penelitian ini

\section{Hasil dan Pembahasan}

\section{Dana Desa dan Problematika Pengelolaan}

Sebagai elemen terkecil pemerintah, desa yang saat ini dibekali kebebasan dalam mengelola pemerintahan juga dituntut untuk mampu berinovasi dalam hal mengelola keuangan terutama terkait dana desa. Skema pengalokasian dana desa merata sebesar 90\% untuk semua desa, sedangkan alokasi 10\% lagi didistribusikan merata dan proporsional dengan mempertimbangkan aspek jumlah penduduk, jumlah penduduk miskin, luas wilayah, dan tingkat kesulitan geografis (Aziz, 2016). Dana desa dapat menjadi alat motivasi bagi pemerintah desa untuk bekerja maksimal, efektif dan efisien sesuai dengan tujuan pemberian dana desa, yaaitu kesejahteraan masyarakat. Selain itu, dana desa juga dapat digunakan sebagai alat komunikasi dan koordinasi antara pemerintah desa dan masyarakat dengan melibatkan masyarakat dalam proses pembangunan desa melalui berbagai pembangunan infrastruktur dan pemberdayaan masyarakat. Penggalian potensi yang dimiliki desa pada akhirnya akan mewujudkan masyarakat yang mandiri, secara ekonomi, soisl, agama, dan budaya. Satu hal yang harus dipahami, pemberdayaan bukan hanya dilihat dari sisi kesempatan usaha dan modal bisnis, namun juga dari sisi perubahan struktur sosial ekonomi yang dapat dilihat di masyarakat (Dewanta, 2016). Saat ini, Pemerintah Pusat mengalokasikan dana desa untuk menciptakan kesejahteraan masyarakat dan dana desa yang dialokasikan mengalami peningkatan setiap tahunnya. Hal tersebut dengan mempertimbangkan kebutuhan desa yang yang mendesak untuk segera diselesaikan. Terjadi peningkatan yang signifikan terkait alokasi dana desa yaitu dengan rincian Rp. 20,67 triliun (2015), Rp. 46,98 triliun (2016), Rp. 60 triliun (2017), Rp. 60 triliun (2018), dan 70 triliun (2019). Dana desa tersebut diberikam untuk seluruh desa di Indonesia.

\section{Grafik 1}


Dana Desa yang bersumber dari APBN Meningkat setiap Tahun

Sumner : data diolah

Dana desa di Provinsi Aceh disebut sebagai Dana Gampong (DG) dan seperti dana desa yang mengalami peningkatan setiap tahunnya, hal yang sama juga berlaku untuk alokasi dana gampong di Aceh. Sebagai ilustrasi, dengan 6.474 jumlah desa, pada tahun 2015 Provinsi Aceh memperoleh Rp. 479,77 juta per desa dan pada tahun 2016 memperoleh Rp. 815,97 juta per desa. Namun demikian, dalam pelaksanaannya pengelolaan dana desa masih mengalami banyak kendala dan masalah. Tidak efisien dan efektifnya pengelolaan dana desa menjadi sorotan masyarakat terutama dugaan korupsi dan penyelewangan dana desa yang dilakukan oleh pemerintah desa. Banyak kajian yang berbicara mengenai lemahnya pengelolaan dana desa, misalnya yang dilakukan oleh Badan Pengawas Keuangan dan

Pembangunan (BPKP) tahun 2015 menyatakan bahwa berdasarkan evaluasi terdapat 15.100 potensi kelemahan akuntabilitas pengelolaan dana desa. Selain itu, lembaga anti korupsi seperti KPK dan juga hal tersebut ditemukan potensi korupsi dana desa. Selain kapasitas dan desa menjadi terkendalanya penggunaan dana

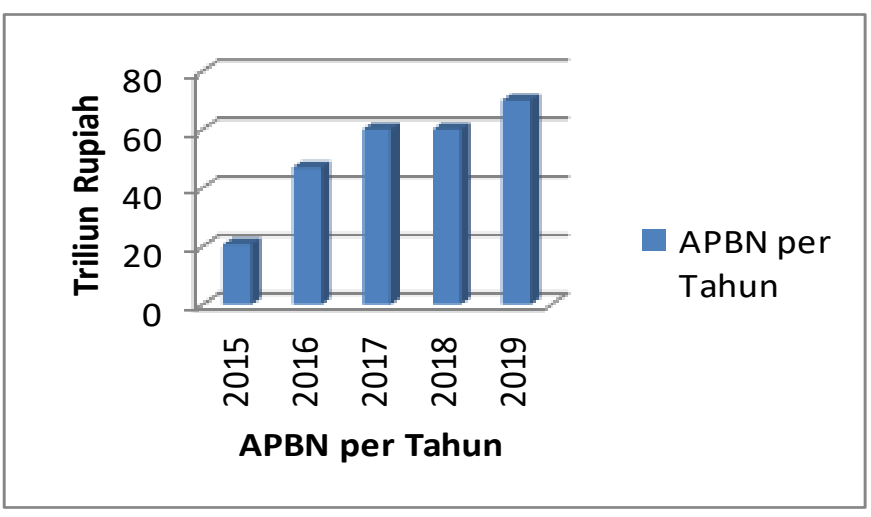

APBDesa belum atau terlambat ditetapkan, perubahan regulasi yang tidak dipahami dengan baik oleh aparatur desa, laporan penggunaan anggaran desa yang belum dibuat, dokumen
LSM Fitra (2016) mengkonfirmasi bahwa banyak permasalahan dan dalam pengelolaan itu, lemahnya kapabilitas aparatur sebab penyaluran dan desa, misalnya 
perencanaan yang belum ada, hingga sempitnya waktu penggunaan dan penyerapan anggaran (Sulumin, 2015).

\section{Inovasi Pengelolaan Dana Desa Melalui Klinik Gampong}

Klinik Gampong adalah pusat peningkatan kapasitas pemerintahan gampong (desa) khususnya aparatur desa terpadu yang dikoordinir oleh camat dan dikelola oleh sumber daya manusia yang ada di kecamatan seperti staf kecamatan, pendamping desa dan pendamping local desa Kecamatan Arongan Lambalek. Kecamatan Arongan Lambalek terdiri dari 27 desa dan 3 diantaranya merupakan desa terpencil, sehingga memerlukan usaha yang ekstra bagi petugas klinik gampong untuk melaksakan penguatan kapasitas aparatur desa. Seperti dengan menunggu aparatur gampong datang ke klinik gampong maupun melakukan aksi jemput bola ke setiap desa. Sejarah awal lahirnya klinik gampong di Kecamatan Arongan Lambalek Kabupaten Aceh Barat disebabkan oleh kondisi kapasitas aparatur desa masih rendah, pelatihan bagi aparatur desa yang dilakukan oleh pemerintah daerah belum efektif, dan peran kecamatan dalam koordinasi, pembinaan, dan pengawasan belum optimal. Sehingga, diperlukan upaya peningkatan kapasitas aparatur kecamatan sebagai Pembina Teknis Pemerintahan Desa (PTPD).

Dilatarbelakangi oleh kondisi tersebut maka Camat Arongan Lambalek membangun komitmen bersama dengan aparatur kecamatan untuk membentuk klinik gampong terutama terkait desain model, pemetaan, dan pemenuhan sumber daya tim pengelola klinik gampong. Pelaksanaan klinik gampong ini selanjutnya didukung oleh regulasi dan pembiayaan. Selanjutnya adalah tahap peningkatan kapasitas tim pengelola klinik gampong melalui berbagai pelatihan, operasionalisasi klinik gampong, dan terakhir pelaporan dan monev. Klinik gampong ini didesain sebagai sarana koordinasi pemerintah desa dan lintas sector di kecamatan sebagai koordinasi terkait pelayanan dasar, sarana konsultasi, sarana berbagi pengetahuan, sarana peningkatan kapasistas dan bimbingan, sarana pelaksanaan monitoring dan evaluasi serta sarana penelitian dan pengembangan pengetahuan tentang tata kelola desa. Operasionalisasi klinik gampong ini didukung oleh KOMPAK (Program Kolaborasi Masyarakat dan Pelayanan untuk Kesejahteraan) yang merupakan program kemitraan antara Pemerintah Australia dengan Pemerintah Indonesia dalam upaya pengentasan kemiskinan nasional sesuai dengan Rencana Pembangunan Jangka Menengah Nasional (RPJMN). Dalam pelaksanaannya, kegiatan di klinik gampong difasilitasi oleh tenaga ahli peningkatan kapasitas aparatur desa, Tujuannya adalah sebagai terobosan inovatif untuk mendekatkan pelayanan dengan masyarakat, menyediakan sumber daya manusia yang mumpuni sehingga nantinya terampil dalam melaksanakan pendampingan bagi aparatur gampong.

Harapan dari keberadaan klinik gampong ini adalah agar aparatur gampong dan masyarakat tidak akan kesulitan untuk mendapatkan informasi dan pengetahuan terkait penyelenggaraan pemerintah gampong dan pengelolaan dana desa karena akses informasi sudah dekat, paratur gampong dapat datang dan berdiskusi langsung dengan tim di klinik gampong yang berkantor di Balai Kecamatan yang terletak di belakang Kantor Camat Arongan Lambalek dan mereka dapat berkonsultasi langsung dengan ahlinya setiap hari selasa dan kamis pukul 
09.00-16.00 WIB setiap minggunya. Program yang bertujuan untuk memberikan informasi dan advokasi secara optimal dalam meminimalisasi timbulnya permasalahan di gampong (desa). Persoalan yang paling banyak terjadi di Kecamatan Arongan Lambalek tempat penelitian dilakukan adalah kurangnya pengetahuan, pengalaman, dan tidak adanya pelatihan bagi bendaraha desa terkait pengelolaan dana desa akibatnya timbul masalah terlambat siapnya LPJ keuangan desa bahkan terkadang juga tidak selesainya LPJ keuangan desa yang berakibat pencairan dana desa untuk tahap selanjutnya menjadi terlambat atau tidak dicairkan. Persoalan ini jika tidak segera diselesaikan berdampak langsung bagi upaya penciptaan kesejahteraan masyarakat di desa. Dengan adanya klinik gampong maka upaya penciptaan kesejahteraan dapat lebih mudah dilakukan dan dikontrol oleh pemerintah daerah melalui koordinasi, konsultasi, berbagi pengetahuan, pelatihan pembimbingan, dan monitoring dan evaluasi serta penelitian tentang desa. Klinik gampong berlokasi di kota kecamatan, Drien Rampak dan setiap bendahara, sekretaris dan kepala desa dapat mengadukan keluhan mereka atau belajar cara menyusun laporan di klinik gampong yang terletak di balai kecamatan. Tugas utama petugas klinik gampong adalah membantu dalam hal administratif seperti (1) menyusun APBG (anggaran pendapatan dan belanja gampong); (2) membantu dalam penginputan data perencanaan dan penganggaran (pengelolaan keuangan desa) dalam siskeudes; (3) dalam hal pemberdayaan masyarakat desa.

Penyusunan APBDes atau jika di Aceh disebut sebagai APBG merupakan hal yang membingungkan dan sulit dilakukan oleh aparatur desa sehingga biasanya aparatur desa akan menunda-nunda pekerjaan yang pada akhirnya berdampak pada terlambatnya proses perencanaan dan pelaksanaan pembangunan di desa. Beberapa sebab mengapa menyusun APBDes ini sulit adalah pertama masih ada kepala desa yang tidak tahu APBDes itu apa biasanya mereka adalah kepala desa, bendahara, atau aparatur desa lainnya yang baru terpilih, kedua adalah aparatur desa belum memahami apa saja komponen yang terdapat dalam APBDes, ketiga masih ada yang menyusun RKPDes setelah APBDes, keempat APBDes masih dianggap barang langka dan rahasia, kelima masih sering menggunakan teknik copy paste atau mencontoh milik desa lain, keenam masih banyak APBDes yang dibuat asal jadi dan asal-asalan. Oleh karena itu penting untuk dilakukan pendampingan oleh tim pengelola klinik gampong yang terdiri dari pendamping desa, pendamping local desa, petugas kecamatan dan staf ahli yang didatangkan khusus jika terdapat persoalan yang tidak mampu dipecahkan oleh tim pengelola klinik gampong yang ada di kecamatan.

\section{Gambar 1}

Konsultasi Kepala Desa terkait Penyusunan APBDes bersama Tim Pengelola Klinik Gampong 


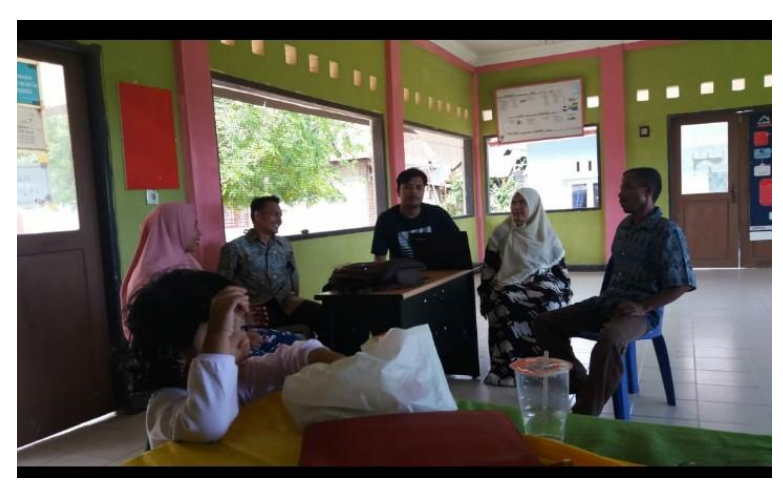

Sumber : Data diolah

Pada dasarnya penginputan data perencanaan dan penganggaran atau pengelolaan keuangan desa dalam aplikasi siskeudes (sistem keuangan desa) masih merupakan hal baru bagi sebagian aparatur desa. Beberapa persoalan yang sering terjadi adalah aparatur desa lupa menginput penerimaan desa (penatausahaan), salah memasukkan data yaitu ketika jumlah yang dibelanjakan melebihi jumlah pendapatan yang dientry (penganggaran), seringkali dalam belanja bidang tidak sesuai kaidah 30\%-70\% sehingga menimbulkan error penganggaran, terkadang ketika ingin belanja namun uang belum dicairkan atau diambil di bank (penatausahaan), lupa memasukkan item pajak seperti PPn dan PPh (penatausahaan), dan kesalahan kecil namun sangat berdampak pada gagalnya penginputan di siskeudes adalah pengisian tanggal yang tidak sesuai (penatausahaan). Oleh karena itu, kepala desa sangat memerlukan bantuan tim pengelola klinik gampong untuk membantu mereka dalam penginputan data di siskeudes dan juga menyelesaikan persoalan salah input ketika mereka mengalaminya.

\section{Gambar 2}

Konsultasi Bendahara Desa dan Tim Pengelola Klinik Gampong Terkait Siskeudes

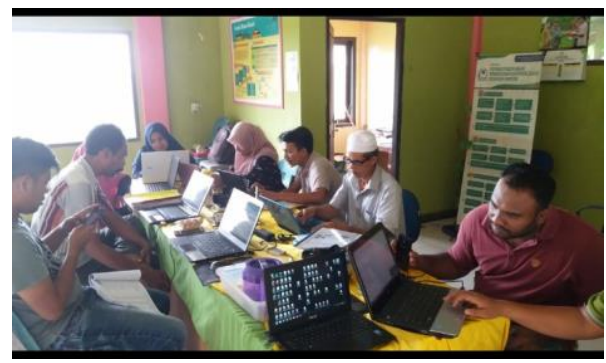

Sumber : Data diolah

Dalam hal pemberdayaan masyarakat desa, tim pengelola klinik gampong mendorong masyarakat desa untuk meningkatkan taraf perekonomian melalui berbagai usaha kreatif yang disponsori oleh BUMD (di Aceh dikenal dengan BUMG) seperti usaha kerajinan tangan dari eceng gondok, baik berupa tas, kerancang, maupun tatakan piring. Eceng gondok adalah bahan baku yang murah dan mudah didapat di Kecamatan Arongan Lambalek. Pelatihan dan pembinaan produksi telah dilakukaan oleh desa bekerjasama dengan pengusaha eksportir untuk selanjutnya dijual di pasar domestic dan internasional, bahkan beberapa wisatawan juga khusus datang ke Arongan Lambalek untuk membeli dan memesan kerajinan tangan dari eceng gondok. 
Setidaknya terdapat tiga desa sentra pengrajin eceng gondok yaitu Desa Kubu, Desa Planteu, dan Desa Cot Jurumudi.

\section{Gambar 3}

Masyarakat Desa Kubu Kecamatan Arongan Lambalek sedang Membuat Tas dari Eceng Gondok

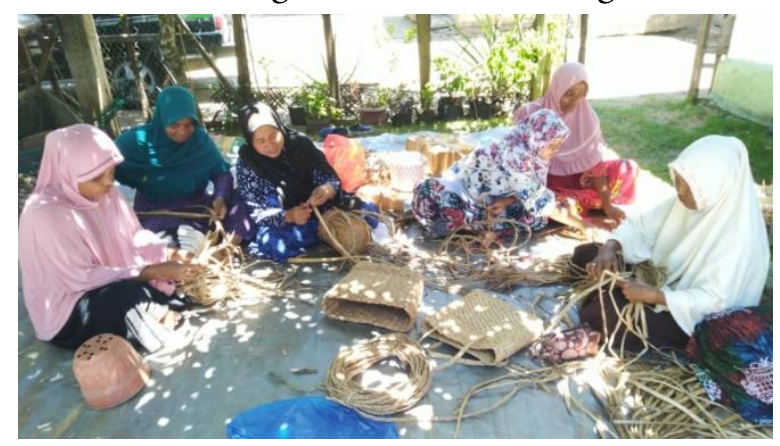

Sumber : Data Diolah

Program pendampingan dalam upaya pemberdayaan masyarakat melalui usaha kerajinan rakyat ini pada akhirnya mampu menggerakkan perekonomian desa selain menggali potensi lokal yang ada di Kecamatan Arongan Lambalek Kabupaten Aceh Barat dan nantinya akan meningkatkan kesejahteraan bagi masyarakat, dan meningkatkan pemberdayaan ekonomi masyarakat kecil. Selain itu, kerajinan tangan eceng gondok ini juga diharapkan mampu menjadi salah satu ikon baru di Aceh Barat. Bentuk kerajinan yang akan didampingi dan diberikan pelatihan bagi masyarakat di Kecamatan Arongan Lambalek ini diantaranya seperti tas, pot bunga, kotak tisu, serta aneka peralatan rumah tangga. Dalam melakukan pendampingan dan pembimbingan bagi aparatur desa di klinik gampong, pemerintah daerah dibantu oleh Pendamping Desa. Menurut data Kementerian Desa, Pembangunan Daerah Tertinggal dan Transmigrasi setidaknya terdapat 37.000 pendamping desa dari 74.957 desa di seluruh Indonesia. Namun demikian, di Kecamatan Arongan Lambalek sebagai kecamatan binaan Kabupaten Aceh Barat terdapat 11 pendamping desa, dengan rincian 4 orang Pendamping Desa (PD) dan 7 orang Pendamping Lokal Desa (PLD).

Perbedaan antara keduanya adalah Pendamping Desa bertugas untuk (1) mendampingi desa dalam perencanaan, pelaksanaan, dan pemantauan terhadap pembangunan desa dan pemberdayaan masyarakat desa; (2) mendampingi desa dalam melaksanakan pengelolaan pelayanan social dasar, pengembangan usaha ekonomi desa, pendayagunaan sumber daya alam dan teknologi tepat guna, pembangunan sarana prasarana desa dan pemberdayaan masyarakat; (3) melakukan peningkatan kapasistas Pemerintahn Desa, lembaga kemasyarakatan desa dalam hal pembangunan dan pemberdayaan masyarakat desa; (4) melakukan pengorganisasian di dalam kelompok-kelompok masyarakat desa; (5) melakukan peningkatan kapasitas bagi kader pemberdayaan masyarakat desa dan mendorong terciptanya kader-kader pembangunan desa yang baru; (6) mendampingi desa dalam pembangunan kawasan pedesaan secara partisipatif; (7) melakukan koordinasi pendampingan di tingkat kecamatan dan memfasilitasi laporan pelaksanaan pendampingan oeleh Camat kepada Pemerintah Daerah. Atau secara singkat dapat 
dikatakan, tugas Pendamping Desa adalah mengurusi persoalan pendampingan desa dari segi pemberdayaan (PDP) dan pendampingan Desa dalam hal Tenaga Infrastruktur (PDTI).

Tabel 2

Pendamping Desa

\begin{tabular}{|c|c|c|}
\hline $\begin{array}{l}\text { Pendam } \\
\text { ping } \\
\text { Desa } \\
\text { (PD) }\end{array}$ & $\begin{array}{l}\text { Pember } \\
\text { dayaan } \\
\text { (PDP) }\end{array}$ & $\begin{array}{l}\text { 1. M. Jamil } \\
\text { 2. Tina Meilina } \\
\text { Putri } \\
\text { 3. Ety Wisma }\end{array}$ \\
\hline & $\begin{array}{l}\text { Tenaga } \\
\text { Infrastr } \\
\text { uktur } \\
\text { (PDTI) }\end{array}$ & $\begin{array}{l}\text { 1. TM Afdhal } \\
\text { Firdaus }\end{array}$ \\
\hline
\end{tabular}

Sumber: Klinik Gampong Keamatan Arongan Lambalek

Selain itu, pemerintah daerah juga melakukan pelayanan jemput bola ke desa-desa apabila ketika menjelang batas akhir pelaporan kepala desa atau bendahara desa belum juga menunjukkan perkembangan atau terkendala dalam proses pelaksanaannya di tempat penelitian ini dilaksanakan yaitu di Kecamatan Arongan Lambalek terdapat 7 orang Pendamping Lokal Desa (PLD).

Pendamping lokal desa tugasnya adalah (1) melakukan fasilitasi perencanaan pembangunan dan keuangan desa seperti memfasilitasi penyusunan RPJMDesa, penyusunan RKPDesa, dan penyusunan APBDesa; (2) melakukan fasilitasi pelaksanaan pembangunan desa seperti memfasilitasi tahapan persiapan pelaksanaan kegiatan dan tahapan pelaksanaan kegiatan pembangunan desa; (3) melakukan fasilitasi pengelolaan keuangan desa dalam rangka pembangunan desa dan pemberdayaan masyarakat desa seperti memfasilitasi pemerintah desa dan pelaksana kegiatan untuk mengembangkan tata kelola pembiayaan pembangunan secara baik dan dapat dipertanggungjawabkan,memfasilitasi pelaksana kegiatan untuk mengelola dana APBDesa dalam rangka pembangunan dan pemberdayaan masyarakat desa; (4) melakukan fasilitasi evaluasi pelaksanaan pembangunan desa seperti memfasilitasi proses evaluasi pelaksanaan sehingga ada pertanggungjawaban pelaksanaan. Keberadaan pendamping desa dan pendamping lokal desa penting mengingat kapasitas dan kapabilitas sumber daya manusia khususnya aparatur desa masih sangat rendah sehingga dikhawatirkan akan menghambat implementasi penggunaan dana desa di Kecamatan Arongan Lambalek.

Tabel 3

Pendamping Lokal Desa

\begin{tabular}{|l|l|l|l|}
\hline No & Nama & Desa & Nama Desa \\
\hline
\end{tabular}




\begin{tabular}{|c|c|c|c|}
\hline 1 & $\begin{array}{c}\text { Syarifudi } \\
n\end{array}$ & 4 & $\begin{array}{l}\text { Ujong Simpang, } \\
\text { Rimba Langgeh, } \\
\text { Alue Bagok, } \\
\text { Panton Makmue }\end{array}$ \\
\hline 2 & Sabirin & 4 & $\begin{array}{c}\text { Pribu, Teupin } \\
\text { Peraho, Cot } \\
\text { Kumbang, Keub }\end{array}$ \\
\hline 3 & $\begin{array}{l}\text { Rusli } \\
\text { Nafi }\end{array}$ & 3 & $\begin{array}{c}\text { Gunong Pulo, } \\
\text { Peulate, Karang } \\
\text { Hampa }\end{array}$ \\
\hline 4 & Rahmat & 4 & $\begin{array}{c}\text { Kubu, Suak } \\
\text { Keumude, } \\
\text { Arongan, } \\
\text { Seunebok Lhong }\end{array}$ \\
\hline 5 & $\begin{array}{l}\text { Zulmufn } \\
\text { azar }\end{array}$ & 4 & $\begin{array}{l}\text { Drien Rampak, } \\
\text { Ujong Beusa, } \\
\text { Simpang Peut, } \\
\text { Cot Buloh }\end{array}$ \\
\hline 6 & $\begin{array}{c}\text { Dedi } \\
\text { Saputra }\end{array}$ & 4 & $\begin{array}{c}\text { Alue Batee, Alue } \\
\text { Sundak, Panton } \\
\text { Bahagia, Cot } \\
\text { Jurumudi }\end{array}$ \\
\hline 7 & Sadariana & 4 & $\begin{array}{l}\text { Suak Ie Buso, } \\
\text { Suak Bidok, } \\
\text { Panton Mutia, } \\
\text { Seunebok }\end{array}$ \\
\hline
\end{tabular}

Sumber: Klinik Gampong Kecamatan Arongan Lambalek

\section{Penutup}

Klinik gampong merupakan sebuah inovasi yang dikembangkan oleh Pemerintah Aceh Barat dan didukung dengan KOMPAK untuk meningkatkaan kapasitas dan kapabilitas aparatur desa di Kecamatan Arongan Lambalek. Tujuan jangka panjangnya adalah agar memudahkan pemerintah desa dalam perencanaaan, pelaaksanaan, dan ketika menyusun laporan 
pertanggungjawaban. Lokasi klinik gampong berada di Balai Kecamatan Arongan Lambalek. Kegiatan pendampingan dan pembimbingan dilakukan oleh pendamping desa, pendamping lokal desa, petugas kecaatan, hingga memaanggil tim ahli secara khusus jika terdapat persoalan terkait pengelolaan dana desa yang tidak mampu diselesaikan tim pengelola klinik gampong.

Klinik gampong beroperasi setiap hari selasa dan kamis mulai pukul 09.00-16.00 WIB, namun demikian tim pengelola klinik gampong yaitu pendamping desa dan pendamping lokal desa tetap dapat dihubungi kapan saja aparatur gampong memerlukan bantuan. Bahkan, pendamping local desa akan melakukaan aksi jemput bola atau mendatangi desa-desa yang belum selesai menyusun laporan pertanggungjawaban.

Inovasi berupa klinik gampong sebagai sebuah wadah konsultasi dan koordinasi terkait pengelolaan dana desa adalah sesuatu yang penting dan harus dilakukan mengingat belum merataanya kualitas sumber daya manusia di Indonesia. Klinik gampong adalah salaah satu inovasi pemerintah Aceh Barat sebagai upaya percepatan peningkatan kualitas aparatur desa dan pencegah potensi penyalahgunaan wewenang dan anggaran yang berujung pada kasus korupsi dana desa dan dalam pelaksanaannya mampu membantu aparatur gampong dalam hal: (1) menyusun APBG (anggaran pendapatan dan belanja gampong); (2) membantu dalam penginputan data perencanaan dan penganggaran (pengelolaan keuangan desa) dalam siskeudes; dan (3) dalam hal pemberdayaan masyarakat desa.

\section{Daftar Pustaka}

Aziz, N. L. L. (2016). Otonomi Desa dan Efektivitas Dana Desa. Penelitian Politik, 13(2), 167191.

Craswell, J. (2014). Penelitian Kualitatif \& Desain Riset: Memilih di Antara Lima Pendekatan. Yogyakarta: Pustaka Pelajar.

Dewanta, A. S. (2016). Otonomi dan Pembangunan Daerah. Unisia. https://doi.org/10.20885/unisia.vol27.iss53.art12

Dura, J. (2016). Pengaruh Akuntabilitas Pengelolaan Keuangan Alokasi Dana Desa, Kebijakan Desa, dan Kelembagaan Desa Terhadap Kesejahteraan Masyarakat. Jurnal Jibeka, 10(1), 26-32.

FITRA. (2018). Banyak Penyimpangan di Dana, Ini Rekomendasi Fitra.

Habibi, F., \& Nugroho, A. (2018). Penerapan Dimensi Akuntabilitas Publik dalam Pencegahan Korupsi Dana Desa di Kabupaten Pandeglang. Jurnal Ilmu Administrasi: Media Pengembangan Ilmu Dan Praktek Administrasi. https://doi.org/10.31113/jia.v15i2.161

Kementerian Keuangan RI. Rincian Alokasi Dana Desa Provinsi/Kabupaten/Kota dalam APBN T.A. 2019. , (2019). 
Makalalag, A. J., Nangoi, G. B., \& Karamoy, H. (2017). Akuntabilitas pengelolaan dana desa di kecamatan Kotamobagu Selatan kota Kotamobagu. Jurnal Riset Akuntansi Dan Auditing "Goodwill."

Maulana, Y. (2016). Membangun Kemandirian Desa dalam Bingkai Otonomi Otonomi Daerah. Penelitian Politik, 261-268(13), 2.

Moonti, R. M., \& Kadir, Y. (2018). Pencegahan Korupsi dalam Pengelolaan Dana Desa. Jurnal IUS Kajian Hukum Dan Keadilan. https://doi.org/10.29303/ius.v6i3.583

Riyanto, T. (2015). Akuntabiltas Finansial Dalam Pengelolaan Alokasi Dana Desa (ADD). StatewideAgriculturalLandUseBaseline2015.https://doi.org/10.1017/CBO9781107415324.04

Sulumin, H. H. (2015). Pertanggung Jawaban Penggunaan Alokasi Dana Desa Pada Pemerintahan Desa di Kabupaten Donggala. E-Jurnal Katalogis, 3(1), 43-53.

Tjandra, W. R. (2003). Perspektif Otonomi Desa Dinamika Desentralisasi. In D. Juliantara (Ed.), Mewujudkan Kabupaten Partisipatif. Yogyakarta: Pustaka Pelajar.

Undang-Undang Republik Indonesia. Undang-Undang No. 6 Tabun 2014 Tentang Desa. , Pub. L. No. 6 (2014).

Watch, I. C. (2018). Outlook Dana Desa 2018: Potensi Penyalahgunaan Anggaran Desa di Tahun Politik. Jakarta.

Widjaja, H. (2008). Otonomi Desa: Merupakan Otonomi yang Asli, Bulat, dan Utuh. Jakarta: PT. RajaGrafindo Persada. 